\title{
Steam gasification of various feedstocks at a dual fluidised bed gasifier: Impacts of operation conditions and bed materials
}

\author{
Christoph Pfeifer • Stefan Koppatz • \\ Hermann Hofbauer
}

Received: 9 December 2010 /Revised: 1 February 2011 /Accepted: 3 February 2011 /Published online: 25 February 2011

(C) Springer-Verlag 2011

\begin{abstract}
Gasification of biomass is an attractive technology for combined heat and power production as well as for synthesis processes such as production of liquid and gaseous biofuels. Dual fluidised bed (DFB) technology offers the advantage of a nearly nitrogen-free product gas mainly consisting of $\mathrm{H}_{2}, \mathrm{CO}, \mathrm{CO}_{2}$ and $\mathrm{CH}_{4}$. The DFB steam gasification process has been developed at Vienna University of Technology over the last 15 years using cold flow models, laboratory units, mathematical modelling and simulation. The main findings of the experimental work at a $100-\mathrm{kW}$ pilot scale unit are presented. Different fuels (wood pellets, wood chips, lignite, coal, etc.) and different bed materials (natural minerals such as olivine, limestones, calcites, etc. as well as modified olivines) have been tested and the influence on tar content as well as gas composition was measured and compared among the different components. Moreover, the influence of operating parameters such as fuel moisture content, steam/fuel ratio and gasification temperature on the product gas has been investigated. DFB steam gasification of solid biomass coupled with $\mathrm{CO}_{2}$ capture, the so-called absorption enhanced reforming (AER) process, is highlighted. The experiments in pilot scale led to commercial realisation of this technology in demonstration scale. Summarising, the DFB system offers excellent fuel flexibility to be used in advanced power cycles as well as in polygeneration applications.
\end{abstract}

Keywords Biomass gasification · Pilot plant · Fuel variation $\cdot$ Fluidised bed $\cdot$ Bed material $\cdot$ Catalyst

\footnotetext{
C. Pfeifer $(\bowtie) \cdot$ S. Koppatz $\cdot$ H. Hofbauer Institute of Chemical Engineering,

Vienna University of Technology,

Vienna, Austria

e-mail: Christoph.pfeifer@tuwien.ac.at
}

\author{
Symbols and abbreviations \\ AER Absorption enhanced reforming \\ CHP Combined heat and power \\ DFB Dual fluidised bed \\ ECCMB External circulating concurrent moving bed \\ FICFB Fast internally circulating fluidised bed \\ sfr Steam/fuel ratio \\ $m_{\text {fuel_db_in }} \quad$ Mass flow of dry biomass $(\mathrm{kg} / \mathrm{h})$ \\ $m_{\mathrm{w}_{\text {flluid_in }}} \quad$ Mass flow of steam for the fluidisation $(\mathrm{kg} / \mathrm{h})$ \\ $m_{\mathrm{w} \_ \text {fuel_in }} \quad$ Mass flow of water with the biomass $(\mathrm{kg} / \mathrm{h})$ \\ $U$ Superficial gas velocity, related to nominal fuel \\ power capacity $(\mathrm{m} / \mathrm{s})$ \\ $U_{\mathrm{mf}} \quad$ Minimum fluidisation velocity for single particle \\ $(\mathrm{m} / \mathrm{s})$ \\ $U_{\mathrm{t}} \quad$ Terminal velocity for single particle $(\mathrm{m} / \mathrm{s})$
}

\section{Introduction}

Gasification is an upgrading process for solid biomass to produce a valuable gas which can be used for a large variety of applications. Steam gasification leads to a nitrogen-free product gas with a low tar content and a high hydrogen content. Fluidised bed technology is well known for high fuel flexibility and can therefore be applied for various kinds of biogenous feedstock. The gasification reactions are mainly endothermic, where heat has to be supplied to the reactor. This can be done by partial combustion of the biomass (autothermic gasification) or indirect (allothermic gasification) by a heat exchanger or a heat carrier (dual fluidised bed [DFB] gasifier). Autothermic gasification reactors mostly use air as the gasification medium because pure oxygen is economic feasible only in large scale installations. The gained product gas is therefore diluted with nitrogen and, because of the low 
heating value $\left(3-6.5 \mathrm{MJ} / \mathrm{N} \mathrm{m}^{3}\right)$, it is called lean gas. By choosing a DFB configuration, an air separation unit can be avoided which is normally necessary for the production of a nitrogen-free product gas. This leads to an interesting technology also for medium sized gasification plants and is therefore most suitable for biomass.

Most gasification plants are dedicated for combined heat and power production using a gas engine with an electricity generator. However, the steam-blown gasification process offers a wide variety of applications. Heat and power can also be produced via gas engines and via gas turbines or fuel cells. Moreover, gaseous and liquid biofuels can also be produced since these are of increasing importance worldwide as certain amounts are politically required. Such biofuels can be produced by synthesis processes using the product gas from gasification. Biomass to liquids can be obtained by Fischer-Tropsch synthesis (BioFiT) and gaseous biofuels (BioSNG) by a methanation reaction. Finally, the production of a hydrogen-rich gas and even of pure hydrogen from biomass is a future option.

\subsection{Biomass gasification fundamentals}

Gasification technologies are expected to play a key role in expanding the use of biomass as a major renewable energy source. The conversion of solid feedstock to a gaseous fuel significantly increases its potential. The gas can be used for several applications such as co-firing, electricity generation in stand-alone devices or production of gaseous/liquid fuels or chemicals [1].

In a gasifier, biomass is converted at $800-1,200^{\circ} \mathrm{C}$ into gaseous species $\left(\mathrm{H}_{2}, \mathrm{CO}, \mathrm{CO}_{2}, \mathrm{H}_{2} \mathrm{O}, \mathrm{CH}_{4}\right.$, light hydrocarbons), condensable tars (higher hydrocarbons), nitrogen compounds $\left(\mathrm{NH}_{3}, \mathrm{HCN}\right)$, sulphur compounds $\left(\mathrm{H}_{2} \mathrm{~S}, \mathrm{COS}\right)$ and solid particles (dust, char) through reactions with gaseous media such as air, steam or oxygen. Biomass feedstock initially goes through drying and pyrolysis stages in a gasifier where the volatile compounds and char are formed. The volatiles can then react through secondary reactions with each other and the solids present. The final product distribution largely depends on process conditions [2]. Air, oxygen, steam and carbon dioxide as well as combinations of these media are used as gasification agents, which influence the product gas composition heavily.

Gasifiers have been designed in various configurations. According to solid fuel combustion, gasification reactors can be divided into three main groups: fixed bed gasifiers (updraft and downdraft), fluidised bed gasifiers and lessestablished entrained bed gasifiers. Detailed reviews of gasifier options are available [4-7].

In an updraft gasifier, the incoming air flows from the bottom to the top, counter-current to the moving bed. The tar concentration in the product gas at the outlet of the gasifier is relatively high (up to $150 \mathrm{~g} / \mathrm{N} \mathrm{m}^{3}$ [3]) and the tar composition is close to the composition of pyrolysis tar. On the other hand, the updraft gasifier offers the advantage of low product gas outlet temperatures $\left(100-200^{\circ} \mathrm{C}\right.$ [3]) because of the cooling down of the gas by passing the cooler zones above. As a second benefit which should be mentioned is that the requirements of the biomass are quite low (water contents up to $50 \%$ and particle sizes from 20 to $200 \mathrm{~mm}[3])$.

In a downdraft gasifier, the incoming air flows from the top/middle to the bottom, co-current to the moving bed. The main advantage of this system is the small amount of impurities in the product gas ( $\operatorname{tar}$ contents below $6 \mathrm{~g} / \mathrm{N} \mathrm{m}^{3}$ and particle contents below $8 \mathrm{~g} / \mathrm{N} \mathrm{m}^{3}$ [3]). This is due to the gas flow through the hot oxidation zone (temperatures above $1,000^{\circ} \mathrm{C}$ ) where the tars are widely cracked into short-warp compounds. Tars from a downdraft gasifier have a relatively low concentration of oxygenated hydrocarbons in comparison with pyrolysis [1]. A disadvantage of this system is the high product gas outlet temperature. To recover the thermal energy of the product gas, a heat exchanger has to be implemented.

Fluidised bed gasifiers are a more recent development that takes advantage of the excellent mixing characteristics and high reaction rates of this method of gas-solid contacting. As bed material, usually silica sand is used, although alumina and other catalytically active bed materials have been used to reduce tars and modify the product gas composition. Fluidised bed gasifiers are typically operated at temperatures between 800 and $850^{\circ} \mathrm{C}$ [4]. Biomass is fed directly into or on top of the sand bed. Most of the conversion of the feedstock to product gas takes place within the bed. Some conversion to product gas occurs in the freeboard section. The conversion of the biomass can be divided into four steps (drying, pyrolysis, combustion and gasification) and can usually not be clearly separated as in a fixed-bed gasifier. Usually, the reactions occur in a statistically distributed fashion over the whole reaction zone, depending on the fluidisation regime in the gasifier (bubbling, turbulent or fast fluidised beds).

A fluidised bed biomass gasifier produces usually a product gas with a tar concentration between 1 and $20 \mathrm{~g} / \mathrm{N} \mathrm{m}^{3}$ [8]. The particle content in the product gas is clearly higher than in the product gas of fixed bed gasifiers.

Fluidised bed gasifiers can be categorised into two groups: bubbling fluidised bed and circulating fluidised bed. Bubbling fluidised bed gasifiers are operated with low fluidising velocities to avoid discharge of bed material. The energy needed for the gasification reactions is provided by partial combustion or is introduced over a heat exchanger into the fluidised bed. 
In contrast to bubbling fluidised beds, circulating fluidised beds work with higher gas velocities and smaller bed material particles. Therefore, large amounts of solids are entrained with the product gas. These systems were developed so that the entrained material is recycled back to the fluid bed to improve the carbon conversion efficiency compared with the single fluid bed design. A fundamental advantage of circulating fluidised bed gasifiers is the smaller cross-sectional dimensions at consistent capacity. However, this leads to higher reactors.

The dual (twin) fluidised bed gasifier belongs to the group of circulating fluidised bed gasifiers and the principles are explained in detail in Sections 1.2 and 1.3.

In entrained flow gasifiers, no inert material is present but a finely ground feedstock is required. Entrained flow gasifiers operate at high temperatures $\left(1,200-1,500^{\circ} \mathrm{C}\right)$, depending on whether air or oxygen is employed, and hence the product gas has low concentrations of tars and condensable gases. However, this high-temperature operation creates problems of materials selection and ash melting. Conversion in entrained flow reactors effectively approaches $100 \%$, whereas there is little experience with biomass in such systems $[4,9]$.

Considering the thermo-chemical conversion with regard to the gaseous products, the idealised overall reaction of the steam gasification can be expressed as follows (Eq. 1).

$\mathrm{C}_{x} \mathrm{H}_{y} \mathrm{O}_{z}+(x-z) \mathrm{H}_{2} \mathrm{O} \rightarrow x \mathrm{CO}+(y / 2+x-z) \mathrm{H}_{2}$

However, stoichiometric and full conversion in terms of carbon monoxide and hydrogen is not achieved in practice. Thus, the gasification yields further permanent gases: $\mathrm{CO}_{2}, \mathrm{CH}_{4}$ and light hydrocarbons $\left(\mathrm{C}_{2} \mathrm{H}_{4}, \mathrm{C}_{2} \mathrm{H}_{6}\right.$, $\mathrm{C}_{3} \mathrm{H}_{8}$ ). Besides the permanent gas components, higher hydrocarbons $\left(\mathrm{C}_{n} \mathrm{H}_{m}\right)$ are generated. Steam and dry reforming of the hydrocarbons can be expressed according to Eqs. 2 and 3.

$\mathrm{C}_{n} \mathrm{H}_{m}+n \mathrm{H}_{2} \mathrm{O} \rightarrow n \mathrm{CO}+(n+m / 2) \mathrm{H}_{2}$

$\mathrm{C}_{n} \mathrm{H}_{m}+n \mathrm{CO}_{2} \rightarrow 2 n \mathrm{CO}+(m / 2) \mathrm{H}_{2}$

Furthermore, the gas composition is mainly influenced by the CO-shift reaction (Eq. 4).

$\mathrm{CO}+\mathrm{H}_{2} \mathrm{O} \leftrightarrow \mathrm{CO}_{2}+\mathrm{H}_{2}$

Apart from the homogeneous gas-gas reactions, the residual char reacts with the present gas species which is generally the gasification agent (Eqs. 5 and 6).

$\mathrm{C}+\mathrm{H}_{2} \mathrm{O} \leftrightarrow \mathrm{CO}+\mathrm{H}_{2}$

$\mathrm{CO}+\mathrm{CO}_{2} \leftrightarrow 2 \mathrm{CO}$
However, it has to be considered that the reaction kinetics of the heterogeneous solid-gas reactions are much slower than the homogeneous gas-gas reactions.

\subsection{Overview on DFB gasifiers}

This section presents recent activities concerning gasification in DFB reactor systems. Comprehensive reviews have been published by Corella et al. [10], Frey [11] and Göransson et al. [12]. The ECCMB (external circulating concurrent moving bed) system combines a transporting fluidised bed, which acts as the combustion zone, and a gas-solid concurrent downflow-moving bed as the gasification zone [13]. Olivine is used as the heat carrier as well as the catalyst to reform the tars. The combustion reactor is fluidised with air, whereas steam is used for the gasification part. The fuel particles are introduced to the system into the gasification section. Ungasified charcoal is transported to the combustion zone and combusted to heat up the bed material. At the Dalian University of Technology, China, a pilot plant is in operation with a fuel mass flow of about $1 \mathrm{~kg} / \mathrm{h}$. The product gas consists mainly of hydrogen (2540 vol.\%), $\mathrm{CO}$ (50-30 vol.\%), $\mathrm{CO}_{2}$ (10-15 vol.\%) and $\mathrm{CH}_{4}$ (10 vol.\%), depending on the gasification temperature $\left(650-800^{\circ} \mathrm{C}\right)$ and the steam to biomass ratio $(0.2-1.2)$.

At the University of Siegen, Germany, the so called Herhof-IPV process is under investigation [14]. The process consists of parallel operation of a fixed bed gasifier and a bubbling fluidised bed reactor as the combustor. Municipal waste is used as the fuel and silica sand is used as the bed material. The pilot plant has a fuel power of $150 \mathrm{~kW}$ and the biomass is fed in the fixed bed, dried, pyrolised and gasified. Since steam is used in the upper part of the fixed bed as well as in the loop seals, the product gas has less than 7 vol.\% nitrogen and a lower heating value of about $13.3 \mathrm{MJ} / \mathrm{N} \mathrm{m}^{3}$.

At Ishikawajima-Harima Heavy Industries Co. (Japan), a novel DFB system has been developed to gasify residues from the food industry [15]. The system concentrically combines a bubbling fluidised bed gasification zone and a pneumatic transport riser as the combustion zone. The gasification zone is fluidised by steam and the combustion zone by air. The resulting product gas composition is comparable to the above-described systems. As an advantage of this system, it should be mentioned that, due to the compact design, heat losses can be minimised. At Chalmers University, a DFB system is in operation which incorporates a bubbling fluidised bed with a circulating fluidised bed for steam gasification of woody biomass. The bubbling fluidised bed $\left(2 \mathrm{MW}_{\text {th }}\right)$ is combined with an existing circulating fluidised bed boiler of $12 \mathrm{MW}_{\mathrm{th}}$, [16]. At the University of Canterbury (Christchurch, New Zealand) at DFB gasifier of $100 \mathrm{~kW}_{\text {th }}$ has been in operation since 2007 [17]. 
1.3 Dual fluidised bed steam gasification at Vienna University of Technology

Biomass steam gasification allows for the conversion of solid biomass to a medium calorific gas $\left(12-14 \mathrm{MJ} / \mathrm{N} \mathrm{m}^{3}\right)$ consisting mainly of $\mathrm{H}_{2}, \mathrm{CO}, \mathrm{CO}_{2}, \mathrm{CH}_{4}$ and $\mathrm{H}_{2} \mathrm{O}$ (see Table 1; details about the absorption enhanced reforming [AER] process are discussed in Section 1.4). At Vienna University of Technology, the DFB steam gasification technology has been developed to provide the heat for the gasification reactor by circulating the bed material. This system is a further development of the so-called FICFB technology (fast internally circulating fluidised bed) which can be found described by Hofbauer et al. [18, 19]).

Figure 1 shows the principle of the DFB steam gasification process and Fig. 2 shows how this principle is implemented. The biomass enters a bubbling fluidised bed gasifier where drying, thermal degasification and partially heterogeneous char gasification take place at bed temperatures of about $850-900^{\circ} \mathrm{C}$. Residual biomass char leaves the gasifier together with the bed material through an inclined, steam-fluidised chute towards the combustion reactor. The combustion reactor is used for heating up the bed material and is designed as a fast fluidised bed (riser). Air is used as the fluidisation agent in the riser. After particle separation from the flue gas in a cyclone, the hot bed material flows back to the gasifier via a loop seal. Both connections, the loop seal and the chute are fluidised with steam, which effectively prevents gas leakage between the gasification and combustion zones and also allows for high solid throughput. The temperature difference between the combustion and the gasification reactor is determined by the energy needed for gasification as well as the bed material circulation rate. The system is inherently autostabilising, since a decrease of the gasification temperature leads to higher amounts of residual char which result in more fuel for the combustion reactor. This, in turn, transports more energy into the gasification zone and thereby stabilises the temperature. In practical operation, the gasification temperature can be influenced by the addition of fuel (e.g. recycled product gas, saw dust, etc.) into the combustion reactor (shown in Figs. 1 and 3 as Add. fuel). The pressure in both the gasification and combustion reactors is close to atmospheric conditions. The process yields two separate gas streams, a high quality product gas and a conventional flue gas, at high temperatures. The product gas is generally characterised by a relatively low content of condensable higher hydrocarbons $\left(4-8 \mathrm{~g} / \mathrm{m}^{3}\right.$ of so-called tars, heavier than toluene $)$, low $\mathrm{N}_{2}\left(<1\right.$ vol. $\left.\%_{\mathrm{db}}\right)$ and a high $\mathrm{H}_{2}$ content of $36-42$ vol. $\%_{\mathrm{db}}$ (see Table 1). For practical use, olivine, a natural mineral, has proven to be a suitable bed material with enough resistance to attrition and moderate tar cracking activity.

1.4 Dual fluidised bed steam gasification of solid biomass coupled with $\mathrm{CO}_{2}$ capture

Much work has been done on this field of research. Many studies and experiments have been performed to produce a hydrogen-rich gas $[20,21]$, and on the other hand, to remove $\mathrm{CO}_{2}$ from the gas stream $[22,23]$.

The so-called AER process uses in situ $\mathrm{CO}_{2}$ capture. The principle of the process is shown in Fig. 3 and the typical gas composition for this process is shown in Table 1. The bed material used acts, apart from its function as a heat carrier, as a $\mathrm{CO}_{2}$ adsorbent material and selectively transfers $\mathrm{CO}_{2}$ from the gasification to the combustion reactor. In practical terms, the bed material allows for repeated cycles of carbonation and calcination of $\mathrm{CaO}$ according to Eq. 7 .

$\mathrm{CaO}+\mathrm{CO}_{2} \leftrightarrow \mathrm{CaCO}_{3}$

The absorption-enhanced reforming process is more efficient than conventional gasification with downstream gas cleaning due to (1) the in situ integration of the reaction
Table 1 Typical product gas composition
${ }^{\mathrm{a}}$ AER absorption enhanced reforming (see Section 1.4)

\begin{tabular}{|c|c|c|c|}
\hline Component & Unit & Conventional process & AER process ${ }^{\mathrm{a}}$ \\
\hline $\mathrm{H}_{2}$ & vol.\% ${ }_{\mathrm{db}}$ & $36-42$ & $55-70$ \\
\hline $\mathrm{CO}$ & vol. $\%$ db & $19-24$ & $5-11$ \\
\hline $\mathrm{CO}_{2}$ & vol. $\%$ db & $20-25$ & $7-20$ \\
\hline $\mathrm{CH}_{4}$ & vol. $\%_{\mathrm{db}}$ & $9-12$ & $8-13$ \\
\hline $\mathrm{C}_{2} \mathrm{H}_{4}$ & vol. $\%_{\mathrm{db}}$ & $2.0-2.6$ & $1.4-1.8$ \\
\hline $\mathrm{C}_{2} \mathrm{H}_{6}$ & vol. $\%$ db & $1.3-1.8$ & $0.3-0.6$ \\
\hline $\mathrm{C}_{3}$-Fract. & vol. $\%$ db & $0.3-0.6$ & $0.3-1.0$ \\
\hline Tar & $\mathrm{g} / \mathrm{N} \mathrm{m}_{\mathrm{db}}^{3}$ & $4-8$ & $0.3-0.9$ \\
\hline Dust & $\mathrm{g} / \mathrm{N} \mathrm{m}_{\mathrm{db}}^{3}$ & $10-20$ & $20-50$ \\
\hline $\mathrm{H}_{2} \mathrm{O}$ & vol.\% & $30-45$ & $50-60$ \\
\hline Fuel & & Wood pellets & Wood pellets \\
\hline Bed material & & Olivine & Calcite \\
\hline
\end{tabular}




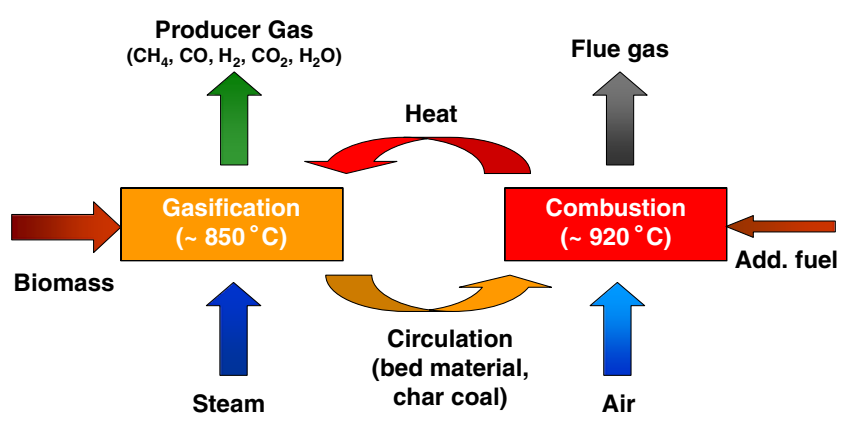

Fig. 1 Principle of steam gasification without selective transport of $\mathrm{CO}_{2}$

heat of $\mathrm{CO}_{2}$ absorption and the water-gas shift reaction heat (both exothermic) into the gasification and (2) the internal reforming of primary and secondary tars, which cuts off the formation of higher tars. Thus, the chemical energy is bound into the permanent gas species (product gas) instead of being bound into the undesired tar compounds. Milne and Evans [24] have classified tars originating from biomass gasification into primary, secondary and tertiary tars corresponding to their temperature range of formation. Furthermore, Evans and Milne [25] specify that primary tars, secondary tars and tertiary tars are generated in the temperature range of $400-700^{\circ} \mathrm{C}, 700$ $850^{\circ} \mathrm{C}$ and $850-1000^{\circ} \mathrm{C}$, respectively [25]. Due to the comparably low gasification temperature in the AER process of $600-700^{\circ} \mathrm{C}$, the formation of tertiary tar compounds is disabled. Hence, the reforming or cracking of tertiary tar compounds is avoided, in particular as the stable structure of aromatic ring compounds is difficult to decompose. The product gas after dust removal can directly be used in a gas engine for electricity generation. Due to the low operation temperature (up to $700^{\circ} \mathrm{C}$ ) and due to $\mathrm{CaO}$ containing bed materials, the proposed process allows the use of problematic feedstocks such as biomass with high mineral and moisture content, e.g. straw, sewage sludge,

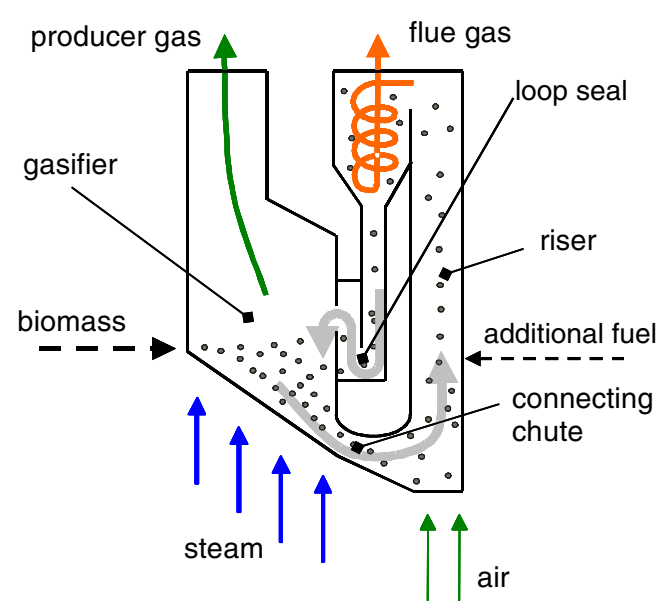

Fig. 2 Dual fluidised bed steam gasifier

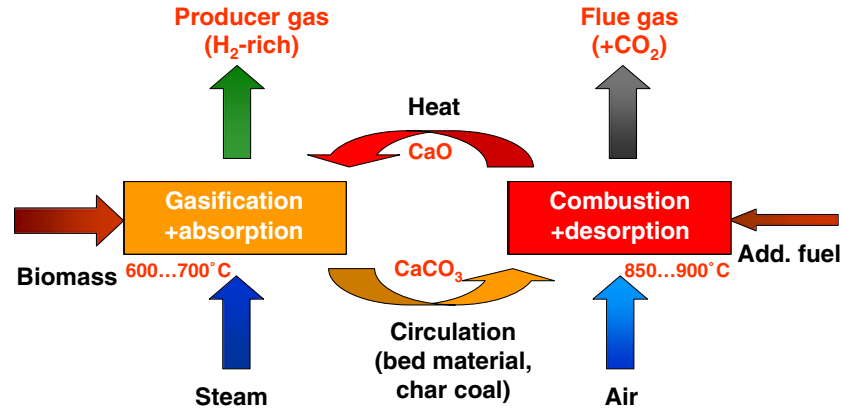

Fig. 3 Principle of steam gasification with selective transport of $\mathrm{CO}_{2}$

etc. leading to an increased market potential for the biomass gasification processes. Details on the AER process can be found in several reports $[26-28,38]$.

\section{Experimental}

\subsection{Experimental setup}

A pilot rig based on the DFB reactor process was constructed at the Vienna University of Technology (Institute of Chemical Engineering). The system was designed for a nominal fuel power of $100 \mathrm{~kW}$ with regard to system up-scale to the megawatt (MW) range. The reactor system of the pilot rig is schematically depicted in Fig. 4.

Design and geometric data of the pilot rig are given in Table 2. The bubbling fluidised bed in the gasification reactor is fluidised with superheated steam generated by an electrically heated steam drum. The combustion reactor (riser) is fluidised with electrically preheated ambient air and operated as a fast fluidised bed. The fluidisation of the riser is injected at two different levels and is therefore distinguished into primary and secondary fluidisation. By means of the primary air injection, a constant supply of solids to the secondary air injection level is realised. Final fast fluidisation with subsequent solid entrainment of the riser is caused by the secondary air fluidisation. Additionally, the char input coming from the gasifier and auxiliary fuel (light fuel oil) are injected together with the primary air and serve to control the temperature level of the gasifier. The entrained solids are separated by means of a deflector plate installed above the cylindrical riser tube.

The riser and gasification reactor are interconnected by steam fluidised loop seals. Furthermore, gas bypass between the riser and gasifier is avoided by solid filled loop seals.

The product gas stream exits the gasifier and passes through a thermo-oil heat exchanger with a gas outlet temperature of about $250^{\circ} \mathrm{C}$. A sampling point for analysis 


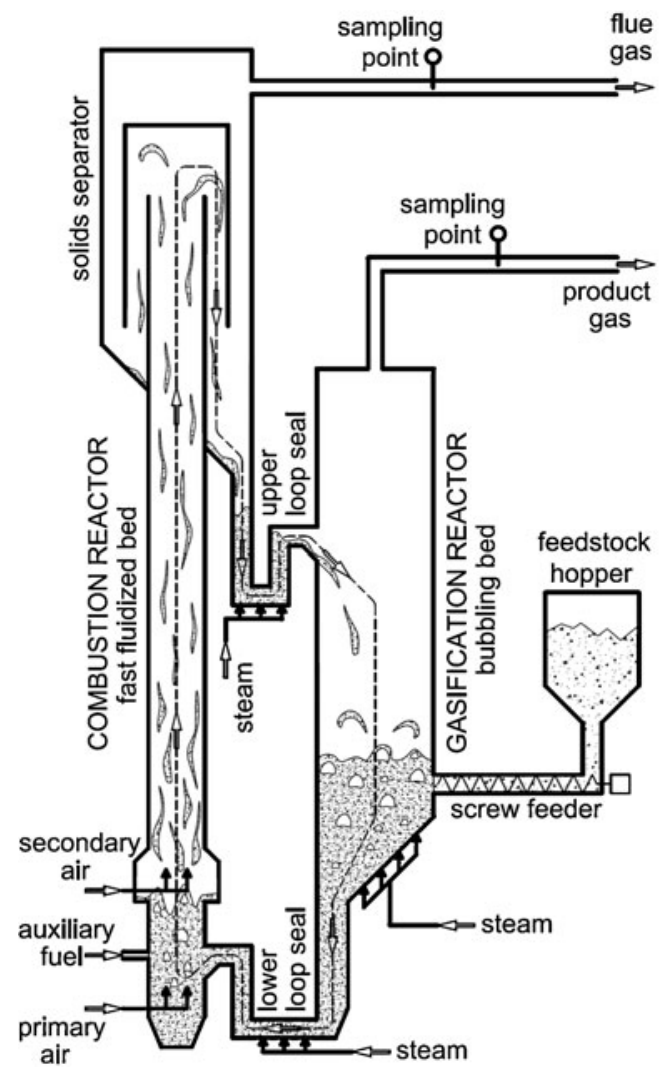

Fig. 4 Dual fluidised bed reactor system of the 100-kW pilot rig

of the product gas composition is installed after the heat exchanger. The product gas stream and flue gas stream are merged together into a post-combustion chamber for complete combustion of flammable species. Prior to the stack, a cyclone separates the particle form the exhaust gas.

Table 2 summarises the characteristic fluidised bed parameters $\left(U\right.$, ratio $U / U_{\mathrm{mf}}$ and $\left.U / U_{\mathrm{t}}\right)$. The details are related to particles (olivine, Geldart particle group B) with a particle size of $500 \mu \mathrm{m}$ and density of $2,850 \mathrm{~kg} / \mathrm{m}^{3}$. The ratios $U / U_{\mathrm{mf}}$ and $U / U_{\mathrm{t}}$ are limited by the desired steam/fuel ratio in the gasifier (steam fluidisation) and the combustion behaviour in the riser (air fluidisation). The fluidisation regime (gasifier and riser) of the DFB reactor system is highlighted according to the regime map suggested by $\mathrm{Bi}$ and Grace [29] in Fig. 5.

\subsection{Analytics}

\subsubsection{Gas measurements}

Permanent gases are analysed by gas chromatographs with thermal conductivity detectors. Moreover, several online gas analysers are in use. Determination of $\mathrm{CO}, \mathrm{CO}_{2}$ and $\mathrm{CH}_{4}(0-100 \%)$ is performed with infrared absorption. Oxygen $(0-25 \%)$ is measured with a paramagnetic cell and hydrogen $(0-100 \%)$ with a thermal conductivity sensor. Furthermore, $\mathrm{NO}_{x}$ (also with speciation of $\mathrm{NO}$ and $\mathrm{NO}_{2}$ ) can be measured by infrared absorption (0-2,500 ppmv). Gas velocity $(0-80 \mathrm{~m} / \mathrm{s})$ is monitored with an ultrasonic sensor.

\subsubsection{Tar measurements}

Gas is sampled isokinetically from the product gas stream via a probe. Particulate matter is separated using a cyclone and a thimble stuffed with quartz wool. To avoid condensation and thereby loss of the analyte in the sampling line, the sampling line is heated, including the solids removal apparatus. Gas is pumped through gas washing bottles where it is scrubbed by a solvent. The solvent is kept at a temperature of $-10^{\circ} \mathrm{C}$. The gas pump also contains a volume meter and a thermometer to allow later for normalisation of the values. The main difference from CEN/TS 15439 is the use of toluene as a solvent, which allows for the easy measurement of the water content in the product gas. Condensed water can be easily removed from the organic toluene phase. The product gas volume
Table 2 Design and geometric data of the $100 \mathrm{~kW}$ pilot rig

\footnotetext{
${ }^{\text {a }} U$ is superficial gas velocity, related to nominal fuel power capacity

${ }^{\mathrm{b}} U_{\mathrm{mf}}$ is minimum fluidisation velocity for single particle

${ }^{\mathrm{c}} U_{\mathrm{t}}$ is terminal velocity for single particle
}

\begin{tabular}{llll}
\hline & Unit & General parameters & \\
\hline Fuel power & $\mathrm{kW}$ & 100 & \\
Feedstock particle size & $\mathrm{mm}$ & Up to 40 (limited by feeding system) \\
Applicable bed material particle size & $\mu \mathrm{m}$ & $200-600$ & Riser \\
& & Gasifier & $750-920$ \\
Operable temperature range & ${ }^{\circ} \mathrm{C}$ & $650-870$ & Air \\
Fluidisation agent & & Steam & Fast fluidisation \\
Fluidisation regime & & Bubbling fluidised bed & - \\
Steam/fuel ratio & - & $0.5-1.2$ & $\sim 9$ \\
$U^{\mathrm{a}}$ & $\mathrm{m} / \mathrm{s}$ & $\sim 0.4$ & $80-85$ \\
Ratio $U / U_{\mathrm{mf}}^{\mathrm{b}}$ & - & $3-4$ & $2-3$ \\
Ratio $U / U_{\mathrm{t}}^{\mathrm{c}}$ & - & $U<<U_{\mathrm{t}}$ & \\
\hline
\end{tabular}




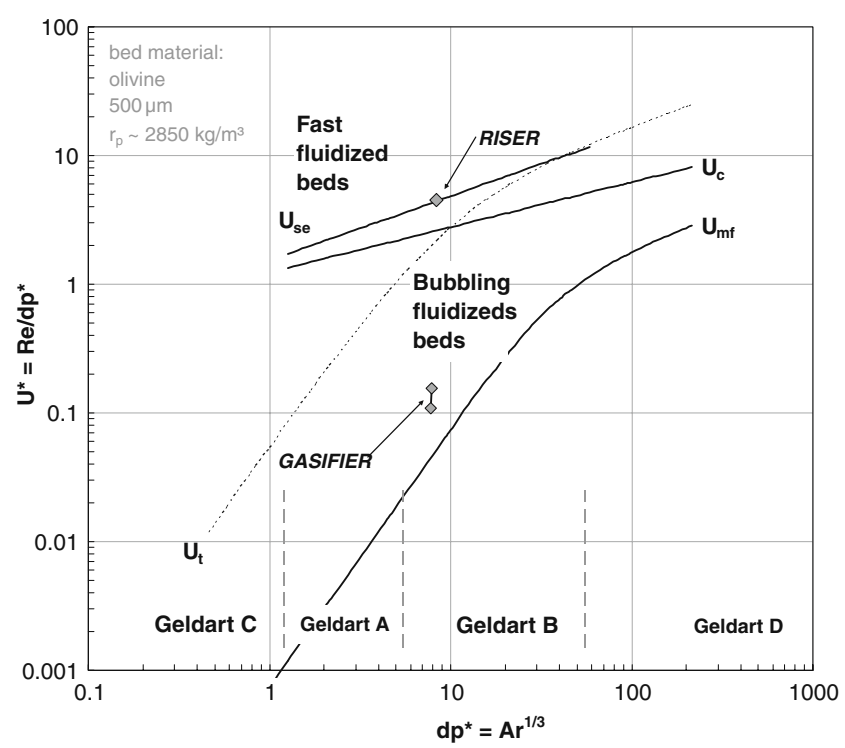

Fig. 5 Mapping of fluidisation regime according to Bi and Grace [29]

sucked through the washing bottle is measured by a gas meter and thus the water content of the product gas can be determined accurately.

After sampling is completed, the solids from the cyclone and the thimble are dried, weighed and are extracted with isopropanol under reflux. The residue is dried and weighed again, thus yielding the values for total particulate matter. The residue gets burned in a muffle furnace, the mass of the ashes is weighed as the amount of dust, and the mass difference equals the amount of entrained coke.

The liquid phases are poured together, such that water is separated and metered volumetrically, yielding the water content in the gas. A sample of the toluene phase and the isopropanol phase (from the extraction) is taken for gas chromatography-mass spectrometry (GC-MS) analysis. The solvent is removed from both phases by evaporation in a rotary evaporator and storage in a drying oven. The residue is weighed and yields the amount of gravimetric tar.

For the measurement of the GC-MS-detectable tar, an internal standard (tetrahydronaphthalene) is added to the samples. The samples are analysed by a Perkin-Elmer Autosystem XL GC with PerkinElmer Turbomass mass spectrometer. All GC-MS measurements are performed in triplicate.

\subsubsection{Ammonia}

Gas is sampled as for the tar measurements using washing bottles. The solvent used in this procedure is diluted sulphuric acid at a temperature of about $2^{\circ} \mathrm{C}$.

The amount of ammonium in this solution is analysed via ion chromatography. Hence, the ammonia concentration in the gas phase can be calculated.

\subsubsection{Hydrogen sulphide}

Gas is sampled again using washing bottles. The absorption liquid is an aqueous potassium hydroxide solution at a temperature of about $2^{\circ} \mathrm{C}$. Subsequent analysis steps are based on the standard ISO 6326-3 "Natural gas-Determination of sulphur compounds Determination of hydrogen sulphide, mercaptan sulphur and carbonyl sulphide sulphur by potentiometry".

\subsubsection{Fuel analyses}

Fuel analyses are carried out according standard methods by the governmentally certified "Testing Laboratory for Combustion Systems" at the Institute of Chemical Engineering, Vienna University of Technology.

\subsection{Bed materials}

Many different bed materials have been tested. As mentioned in Section 1.3, olivine has proven to be a suitable bed material with respect to attrition and tar cracking activity. However, alternatives have been tested such as:

- Silica sand

- Different limestone

- Different calcites

- Olivine

- Fe olivine

- Ni olivine

Limestone is a sedimentary rock. Although it may contain many other minerals, it is primarily composed of the mineral calcite, which is a carbonate mineral and the most stable polymorph of calcium carbonate $\left(\mathrm{CaCO}_{3}\right)$. Depending on the source and the composition, these materials differ significantly in activity as well as attrition resistance. Different materials from different sources and countries have been tested, whereas finally only the material with an attrition rate comparable to olivine was chosen for comparison (see Section 3.5).

\subsection{Fuels}

The demonstration plants in Güssing and Oberwart use wood chips from forestry as fuel. At the pilot scale, the operational experience showed that wood pellets can be used instead of wood chips due to the fact that the gas quality is comparable. Wood pellets offer the advantages of consistent composition and humidity as well as easy handling (no bridging in the fuel feeding system).

Promising alternative types of fuels can be tested in the $100-\mathrm{kW}$ process development unit and after successful 
operation, those materials can be used at the demonstration plants. In the following, the tested fuels are listed:

- Wood pellets

- Wood chips with different water contents

- Bark

- Willow wood chips

- Straw

- Wood/straw mixtures $(80: 20$ and $60: 40$ in terms of weight)

- Sewage sludge

- Lignite

- Hard coal from Poland (in the following termed coal)

- Coal/biomass mixtures (from $0 \%$ to $100 \%$ in terms of energy)

It should be mentioned that the wood chips are the same as those used at the combined heat and power plant in Güssing, Austria, and consist mainly of hardwood (oak, beech), whereas the bark is mainly from softwood as used in the pulp and paper industry (fir). The wood for the mixtures of wood and straw as well as the raw material for the pellets is also hardwood.

\section{Results}

The results as presented in this paper focus on the product gas composition as well as the tar content measured by GCMS and gravimetric method. The following section describes the influence of important operation parameters and different feedstocks on gasification performance. The results derived by variation of the gasification temperature, the steam/fuel ratio, the fuel water content, different feedstock and bed materials are highlighted. Characteristic values describing the reactor and gasification performance are pictured in Figs. 6,7 and 8. The details are related to gasification of wood pellets applying natural olivine as bed material. The gasifier product gas composition is shown in Fig. 6. The permanent gas species represents the main part of the product gas composition. Further gaseous products are $\mathrm{C}_{2} \mathrm{H}_{4}, \mathrm{C}_{2} \mathrm{H}_{6}, \mathrm{C}_{3} \mathrm{H}_{8}$ or tars (higher hydrocarbons) occurring in minor quantities. Besides the desired gas species, gaseous impurities $\left(\mathrm{NH}_{3}, \mathrm{H}_{2} \mathrm{~S}, \mathrm{HCl}\right)$ are formed due to the input of sulphur, nitrogen or chlorine by the feedstock. Generally, hydrogen constitutes the main product gas component due to the application of $\mathrm{H}_{2} \mathrm{O}$ as gasification agent and is significantly influenced by the degree of CO-shift reaction.

Figure 7 shows the progress of mean temperature in the gasifier, in the riser and the pressure drop over the bubbling fluidised bed in the gasifier of the DFB reactor system. The temperature difference between gasifier and riser indicates the solid circulation between riser and gasifier, since the

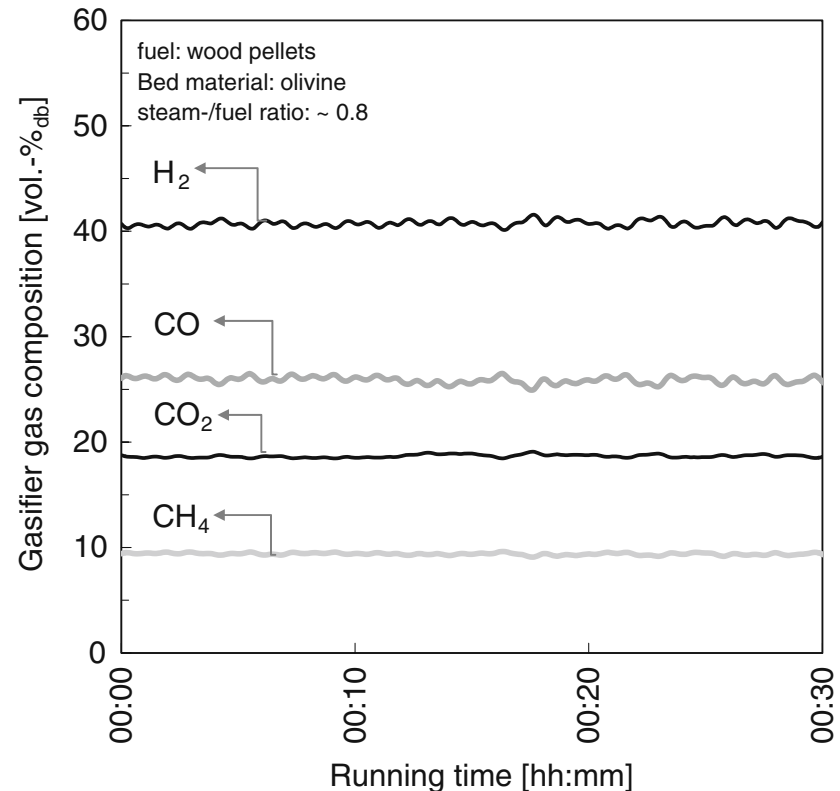

Fig. 6 Product gas composition, fuel: wood pellets, gasification temperature: $850^{\circ} \mathrm{C}$

heat for gasification is supplied by the circulating bed material. The lower the difference in temperature, the higher the solid circulation rate. The pressure drop of the bubbling fluidised bed in the gasifier quantifies the amount of solid inventory. The temperature profile over the gasifier reactor's height is displayed in Fig. 8. Further, geometrical positions and feeding positions are indicated. The position of solid recycle into the gasifier coming from the riser develops a local hot spot. A cold spot is developed in the area of steam injection (fluidisation) due to local cooling.

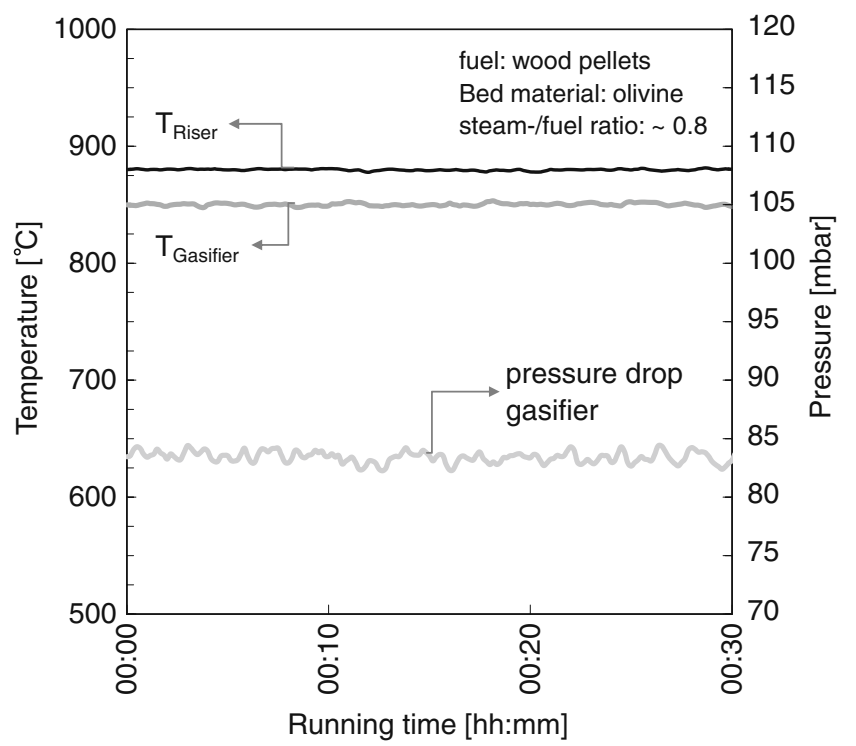

Fig. 7 General process parameters, fuel: wood pellets 


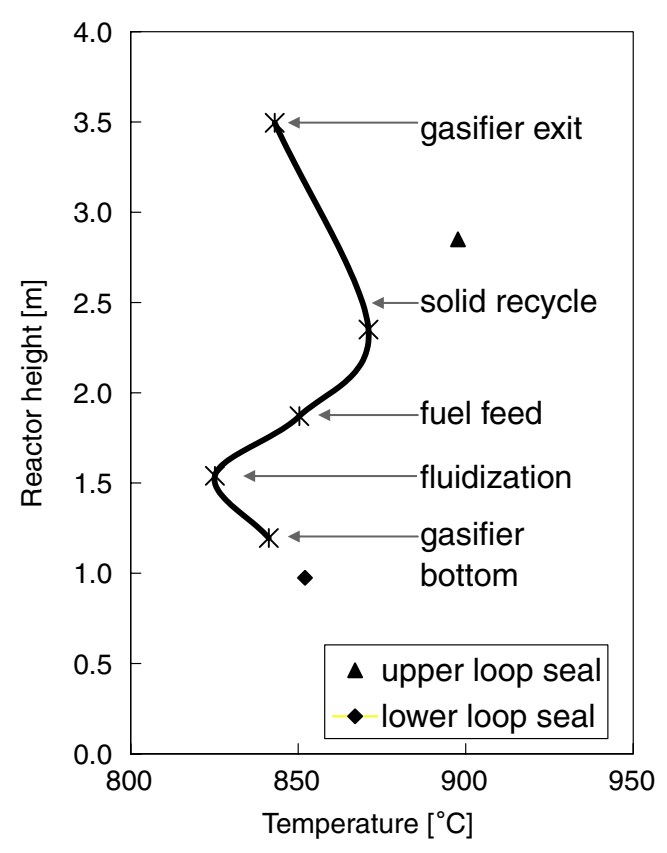

Fig. 8 Gasifier temperature profile over reactor height, wood pellets

However, the temperature increases immediately due to contact with the hot solids.

\subsection{Variation of the gasification temperature}

Figure 9 displays the product gas composition attained by variation of the gasification temperature. Details on these experiments can be found in the work of Hofbauer and Rauch [30] and can be verified by previous experiments

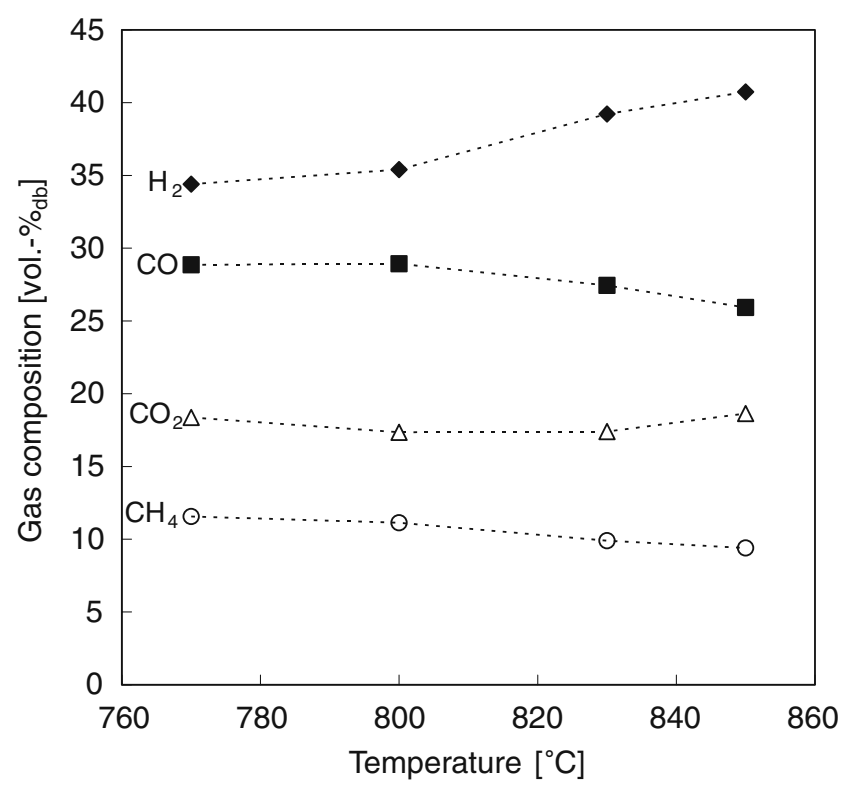

Fig. 9 Product gas composition vs. gasification temperature; fuel: wood pellets, bed material: olivine, steam/fuel ratio: $\sim 0.8$
[31]. The variation of the gasification temperature results in different product gas composition, since the reaction equilibriums and kinetics are influenced.

Higher gasification temperature results in significantly higher hydrogen content and lower carbon monoxide content. The $\mathrm{CO}_{2}$ content is slightly influenced by the temperature. Increasing the temperature decreases the $\mathrm{CH}_{4}$ content. This suggests that higher temperature promotes the conversion of $\mathrm{CH}_{4}$ and the reforming reactions, respectively.

The tar content strongly depends on the gasification temperature. The higher the temperature, the lower the tar content. Thus, a gasification temperature of about $850^{\circ} \mathrm{C}$ is generally preferred since sufficient carbon conversion with regard to the present residence times is achieved.

In summary, it can be stated that with increasing temperature, the gas quality for syngas applications increases and, moreover, the tars decrease [31]. Nevertheless, an optimum has to be found between the required gas quality and the chemical efficiency since higher gasification temperatures lead to higher heat losses.

\subsection{Variation of the steam/fuel ratio}

The fuel water content can be changed independently of the steam/fuel ratio in the gasifier. Figure 10 shows the gas composition dependent on the steam/fuel ratio. Within the investigated range of steam/fuel ratios $(0.3-1.1)$, the methane and carbon monoxide contents decrease, whereas the hydrogen and carbon dioxide contents increase. These results were found independently of the bed material as well as the fuel used. Details on the influence of the steam/

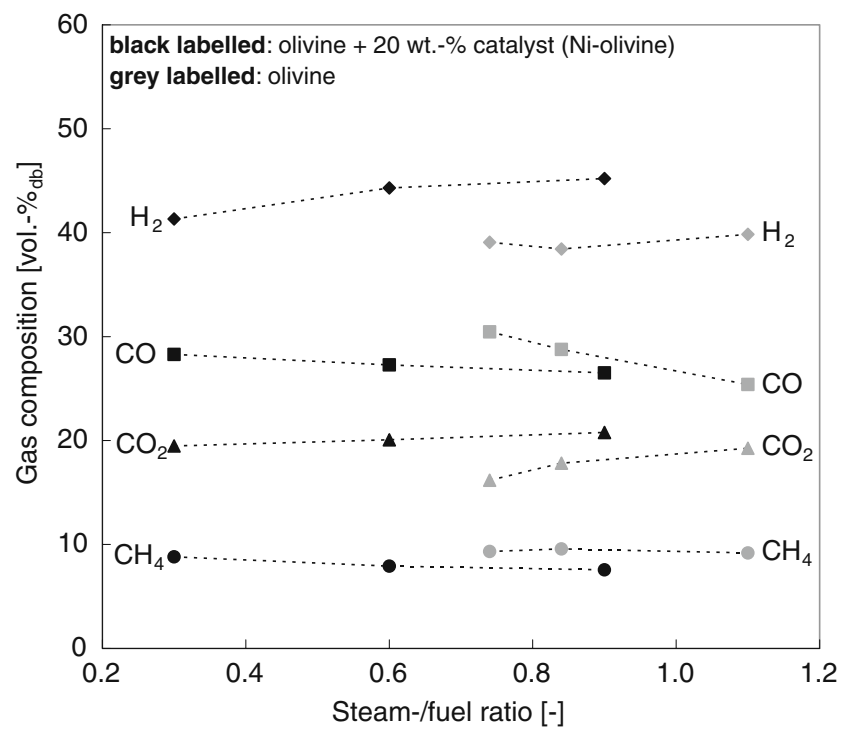

Fig. 10 Product gas composition vs. steam/fuel ratio, gasification temperature: $850^{\circ} \mathrm{C}$, fuel: wood pellets, black labelled: olivine $+20 \mathrm{wt}$. $\%$ catalyst ( $\mathrm{Ni}$ olivine), grey labelled: olivine 
Table 3 Test conditions for the experiments with wood chips with different moisture content

\begin{tabular}{lcccc}
\hline Test run no. & Wood chips particle size $(\mathrm{mm})$ & Gasification temperature $\left({ }^{\circ} \mathrm{C}\right)$ & Moisture content $(\mathrm{wt} . \%)$ & Fuel mass flow $\left(\mathrm{kg} / \mathrm{h}_{\mathrm{db}}\right)$ \\
\hline 1 & $<11$ & 850 & 10 & 22.5 \\
2 & $<11$ & 810 & 38 & 22.5 \\
3 & $11-20$ & 850 & 6 & 22.5 \\
4 & $11-20$ & 850 & 19 & 22.5 \\
5 & $11-20$ & 810 & 6 & 15 \\
6 & $11-20$ & 810 & 19 & 15 \\
7 & $11-20$ & 810 & 30 & 15 \\
8 & $11-20$ & 810 & 40 & 15 \\
\hline
\end{tabular}

fuel ratio on the process have been published previously $[30,32]$.

Moreover, the tar content decreases with increasing steam/fuel ratio. For industrial applications (e.g. heat and power production), an optimum has to be found between overall efficiency of the plant (which decreases with increasing steam/fuel ratio), gas composition and tar levels. There are different requirements for co-firing, combined heat and power production and synthesis applications, respectively. The steam-fuel ratio is calculated by the following equation:

$\mathrm{sfr}=\frac{\dot{m}_{\mathrm{W} \_ \text {fuel_in }}+\dot{m}_{\mathrm{W} \_ \text {fluid_in }}}{\dot{m}_{\text {fuel_db_in }}}$

where sfr denotes the steam/fuel ratio, $m_{\mathrm{w}_{-} \text {fuel_in }}$ is the mass flow of water with the biomass $(\mathrm{kg} / \mathrm{h}), m_{\mathrm{w}_{-}}$fluid_in is the mass flow of steam for the fluidisation $(\mathrm{kg} / \mathrm{h})$ and $m_{\text {fuel_db_in }}$ is the mass flow of dry biomass $(\mathrm{kg} / \mathrm{h})$.

\subsection{Variation of the fuel moisture content}

To compare wood chips with different water contents with respect to their suitability for the gasification process, it is necessary to fix the boundary conditions such as gasification temperature, fluidisation regime as well as fuel power. Generally, by changing one parameter such as steam flow for fluidisation, other parameters also change (e.g. residence time, superficial velocity, etc.). For these test runs, a gasification temperature of 850 resp. $810^{\circ} \mathrm{C}$ and a fuel mass flow of 22.5 resp. $15 \mathrm{~kg} / \mathrm{h}_{\mathrm{db}}$ were adjusted. The temperature in the combustion zone depends on the heat demand in the gasification zone and is in a range between 800 and $890^{\circ} \mathrm{C}$. Table 3 shows an overview over the test conditions applied.

The mass flow of water-free fuel, gasification temperature and the amount of fluidisation vapour entering the gasification part were kept the same for each series of experiments carried out. The mass flow of the circulating bed material was kept constant for all experiments. Using fuel with higher moisture content leads to an increased amount of energy necessary for vaporising the fuel's water, and as a consequence thereof, the temperature in the gasification part decreases. Thus, holding the gasification temperature constant for all the experiments requires additional fuel co-fired in the combustion part.

Table 4 gives an overview of the experimental results for the variation of the fuel water content as well as of the fuel particle size and gasification temperature. The mass flow of steam for fluidisation was kept constant for all test runs (see Tables 3 and 4). However, the steam/fuel ratio differs as the water content varies. It can be seen in Fig. 11 as well as in Fig. 12 that with increasing water content of the fuel, the
Table 4 Product gas composition for the experiments with wood chips with different moisture content

\begin{tabular}{|c|c|c|c|c|c|}
\hline \multirow[t]{2}{*}{ Test run no. } & \multirow[t]{2}{*}{ Steam/fuel ratio (kg/kg) } & \multicolumn{4}{|c|}{ Product gas composition (vol.\%) } \\
\hline & & $\mathrm{CO}$ & $\mathrm{CO}_{2}$ & $\mathrm{CH}_{4}$ & $\mathrm{H}_{2}$ \\
\hline 1 & 0.75 & 20.8 & 27.3 & 11.2 & 35.0 \\
\hline 2 & 1.58 & 18.4 & 26.3 & 10.6 & 35.8 \\
\hline 3 & 0.71 & 24.4 & 21.7 & 11.32 & 35.7 \\
\hline 4 & 0.87 & 20.5 & 25.8 & 11.3 & 36.2 \\
\hline 5 & 1.02 & 22.2 & 25.3 & 11.6 & 34.1 \\
\hline 6 & 1.19 & 18.5 & 28.0 & 11.1 & 34.9 \\
\hline 7 & 1.39 & 18.1 & 28.1 & 11.0 & 36.2 \\
\hline 8 & 1.60 & 16.8 & 26.7 & 10.6 & 37.2 \\
\hline
\end{tabular}




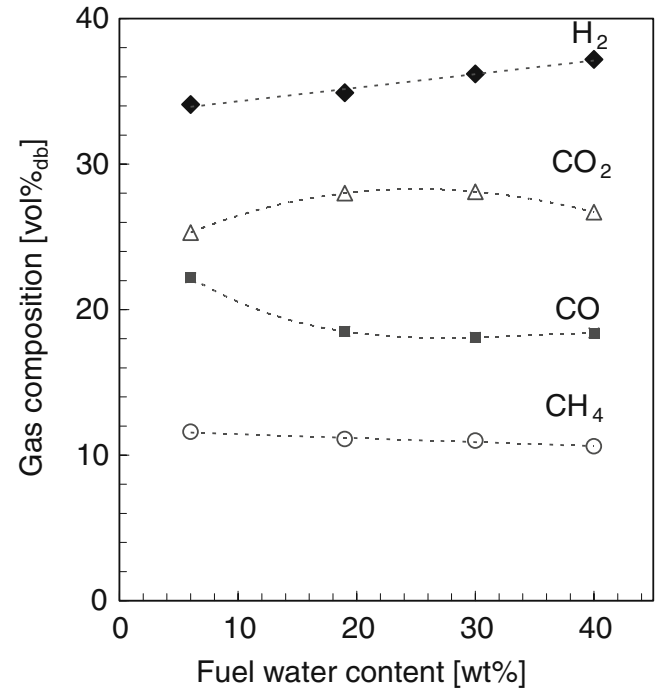

Fig. 11 Product gas composition for wood chips with different moisture contents $(6-40 \mathrm{wt} . \%)$ at $810^{\circ} \mathrm{C}$ gasification temperature; test run nos. 5 to 8

hydrogen values also increase and carbon monoxide decreases.

In addition to the composition of the product gas, its tar content was also measured. The influence of fuel moisture content on the tar content in the product gas is shown in Fig. 13. By far, the highest tar contents are measured when biomass with the lowest water content (6 wt.\%) is gasified. Increasing the fuel water content to $20 \mathrm{wt} \%$ gives the lowest tar contents. If the fuel moisture content is further increased, the tar content again slightly increases, but the measured tar contents are still below the tar contents obtained with the wood chips with a moisture content of $6 \mathrm{wt} . \%$. These findings correlate with experiences gained in Güssing (Austria), where fuel with water contents below

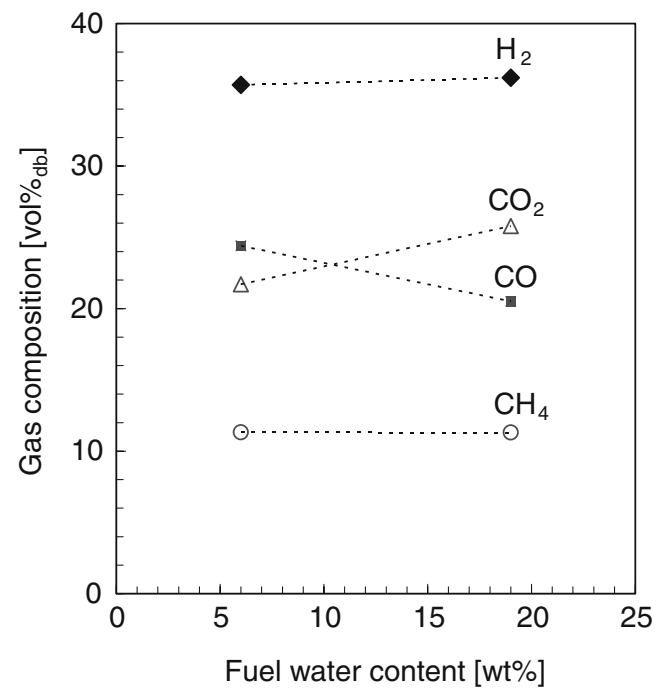

Fig. 12 Product gas composition for wood chips with different moisture contents $\left(6-19\right.$ wt. \%) at $850^{\circ} \mathrm{C}$ gasification temperature; test run nos. 3 to 4

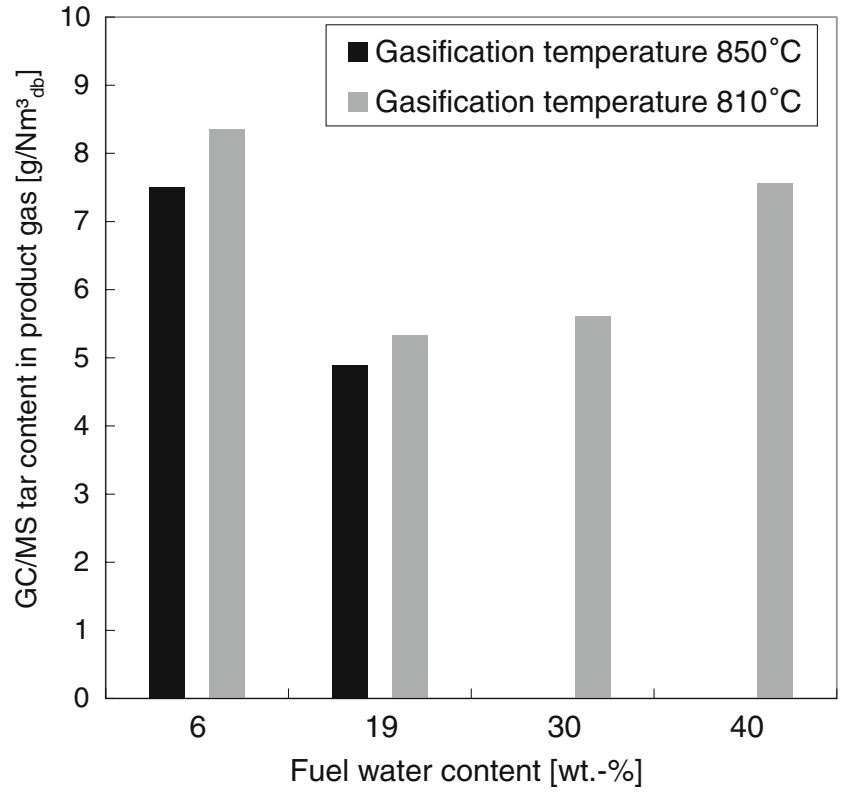

Fig. 13 Tar content in the product gas for wood chips with different moisture contents (6-40 wt.\%) at different gasification temperatures $\left(810 / 850^{\circ} \mathrm{C}\right)$; test run nos. 3 to 8

20 wt.\% led to high tar contents in the product gas and problems with plugging in the product gas heat exchanger. Generally, the fuel as delivered has, depending on the season, moisture contents between 25 and $50 \mathrm{wt} . \%$. Some drying occurs if the feedstock is left in the sun for some time, although only the surface area of the wood chips piles is influenced. Thus, it can be stated that drying of biomass fuel is energetically and operationally advantageous.

\subsection{Variation of the fuel}

The feedstocks, which were successfully tested in the 100$\mathrm{kW}$ dual fluidised bed gasifier at the Vienna University of Technology, are displayed in Table 5. In addition to the arranged biomass fuels, different coals and lignites have also been investigated. For all the presented investigations, the bed inventory of $100 \mathrm{~kg}$ olivine was kept constant as well as the gasification temperature of $850^{\circ} \mathrm{C}$.

It can be seen (Fig. 14) that the gas composition for the different biofuels is in the same range. Coal and lignite show generally higher values for hydrogen and lower methane as well as other gaseous hydrocarbon levels. Coal has been tested in mixtures with wood pellets in ratios of 0 to $100 \%$, and generally the tar content in the product gas of coal gasification is about half the value as for wood gasification. This experimental campaign is detailed by Aigner [33]. The main components of the GC-MS tar are naphthalene, indene and acenaphthalene, which are the same (components as well as composition) for coal as for wood. 
Table 5 Product gas composition for the experiments with different fuels at $850^{\circ} \mathrm{C}$ gasification temperature

\begin{tabular}{lcccc}
\hline \multirow{2}{*}{ Fuel } & \multicolumn{3}{l}{ Product gas composition (vol.\%) } & \\
\cline { 2 - 5 } & $\mathrm{CO}$ & $\mathrm{CO}_{2}$ & $\mathrm{CH}_{4}$ & $\mathrm{H}_{2}$ \\
\hline Wood pellets & 26.1 & 21.3 & 9.9 & 40.3 \\
Wood chips & 24.4 & 21.7 & 11.32 & 37.4 \\
Bark & 23.3 & 18.3 & 8.0 & 44.3 \\
Wood chips (willow) & 21.9 & 24.8 & 10.7 & 39.2 \\
Wood/straw mixture 80:20 wt.\% & 20.3 & 24.3 & 9.9 & 40.4 \\
Wood/straw mixture 60:40 wt.\% & 22.4 & 21.5 & 10.0 & 41.8 \\
Sewage sludge & 16.8 & 26.7 & 8.0 & 41.5 \\
Lignite & 23.0 & 17.2 & 5.3 & 54.5 \\
Wood/coal mixture 50:50 energy\% & 7.7 & 23.85 & 17.7 & 45.8 \\
Coal & 11.5 & 18.0 & 7.9 & 57.9 \\
\hline
\end{tabular}

\subsection{Variation of the bed material}

One essential parameter for a fluidised bed gasification system is the type of bed material which is used. Silica sand is typically used for fluidised bed biomass combustion and also for gasification applications. However, silica sand has no catalytic activity. Bed materials for the dual fluidised bed biomass gasification system are selected by applying the following criteria: attrition resistance, catalytic activity in respect to hydrocarbon and tar reforming. Primary tar reduction is in investigation by several investigators, whereas different catalytic materials are also in discussion. The range of materials usable for catalytic tar reduction includes natural minerals (e.g. dolomite, limestone, olivine, iron ores) as well as synthetic materials (e.g. Ni-supported olivine, Fe-supported olivine, alkali metal based material, char). Comprehensive reviews on the catalysts for biomass gasification and tar reduction, respectively, are given by Abu El-Rub et al. [34], Sutton et al. [35], and Dayton [36].
As mentioned above, olivine, a natural mineral, has proven to be a suitable bed material with enough resistance to attrition and moderate tar cracking activity. Limestone has been tested in comparison to olivine and Table 6 shows the mean product gas compositions for the selected experiments using wood pellets as fuel at a gasification temperature of $850^{\circ} \mathrm{C}$. It appears that a significantly higher hydrogen content of almost 50 vol. $\%{ }_{\mathrm{db}}$ is achieved using limestone in comparison to olivine with $39 \mathrm{vol.} \% \mathrm{db}$. Also, the other gaseous hydrocarbons as well as tars (gravimetric as well as GC-MS) are lower for limestone than for olivine due to the tar reforming reactions favoured by the $\mathrm{CaO}$ [37]. This suggests solid catalysed gas-gas reactions (COshift and reforming reactions).

Gasification has also been investigated comprehensively for the special case when $\mathrm{CaO} / \mathrm{CaCO}_{3}$ is used as the bed material, allowing selective transport of $\mathrm{CO}_{2}$ from the gasification reactor to the combustion reactor by repeated carbonation and calcination. The selective transport of $\mathrm{CO}_{2}$

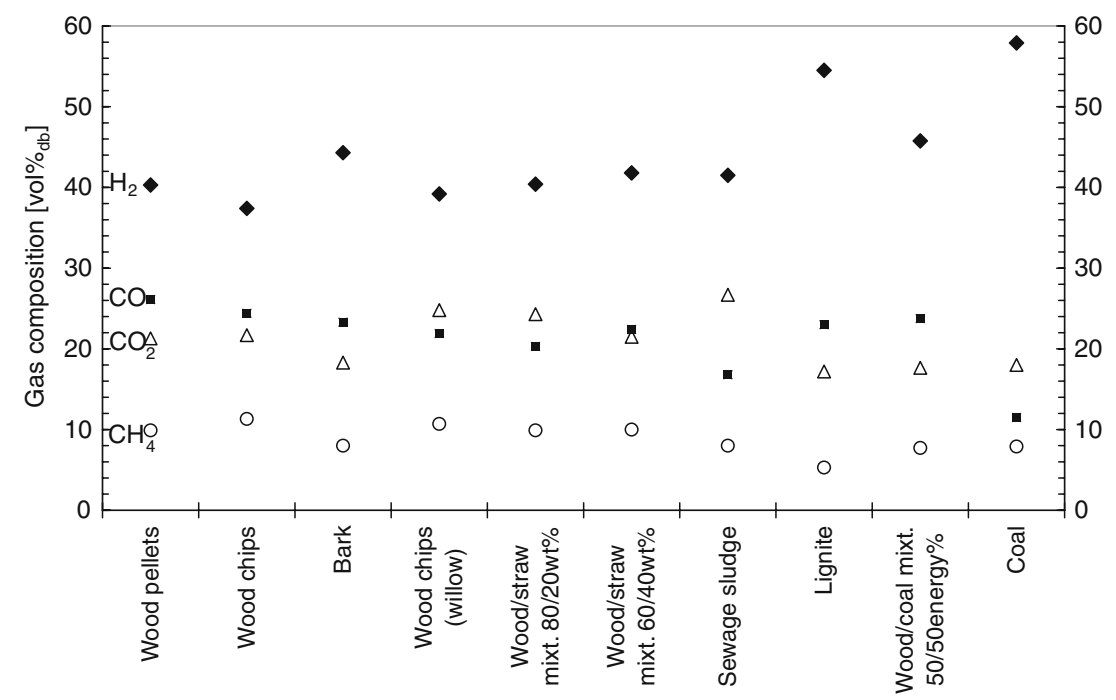

Fig. 14 Product gas composition for the experiments with different fuels at $850^{\circ} \mathrm{C}$ gasification temperature 
Table 6 Effect of bed material different bed materials on product gas composition, fuel: wood pellets (see also Fig. 15)

\begin{tabular}{llllr}
\hline Bed material & \multicolumn{4}{c}{ Product gas composition (vol.\%) } \\
\cline { 2 - 5 } & $\mathrm{H}_{2}$ & $\mathrm{CO}_{2}$ & $\mathrm{CO}$ & $\mathrm{CH}_{4}$ \\
\hline Silica sand & 34.7 & 13.6 & 34.2 & 11.1 \\
Limestone & 48.7 & 21.8 & 17.4 & 8.1 \\
Olivine & 39.2 & 17.4 & 27.4 & 9.9 \\
Fe olivine & 33.4 & 27.1 & 24.6 & 9.4 \\
Ni olivine & 43.9 & 18.8 & 27.2 & 8.3 \\
\hline
\end{tabular}

results in high $\mathrm{H}_{2}$ contents in the produced syngas. The lower operating temperatures in the gasification reactor increase the efficiency of energy conversion [28]. Despite the low gasification temperature, the tar levels are significantly lower than for standard gasification (bed material: olivine, gasification temperature: $850^{\circ} \mathrm{C}$ ). Details on the AER process can be found in several publications [26, 28, 39]. Different limestones applying the AER process have been investigated by Soukup et al. [39] and Höftberger [40].

As a further option, Ni-enriched olivine has been tested successfully since tar levels can be reduced by an order of magnitude and this catalyst shows good behaviour with respect to attrition resistance, stability and steam reforming [32].

A comprehensive summary on investigation with different bed materials has been given by Pfeifer et al. [41] (see Fig. 15). The summary further includes a synthetically ironenriched olivine (Fe olivine), which acts as a catalyst [41]. In addition to the activity in in-bed primary tar reduction, the application of Fe-olivine features oxygen looping between the combustion and gasification reactor. Oxygen transport develops due to cyclic oxidation and reduction of the iron part of the particle. Partial oxidation of iron occurs in the combustion reactor, whereas the reducing gas atmosphere in the gasification reactor reduces the oxidised iron. The influence of oxygen transfer on the gasification is detailed by Koppatz et al. [42].

\section{Conclusion}

Thermo-chemical biomass conversion for the production of chemicals and fuels or combined heat and power offers a number of political, social, economic and, of course, ecological benefits. Although biomass gasification technologies are still under development, they are expected to play a major role in future energy systems. In the middle term, there is a significant need for advanced biomass-toelectricity technologies, while in the long term, the substitution of fossil fuels will be of more importance (e.g. biomass-to-liquid fuels, substitute natural gas).

Until now, all industrial-scale gasifiers using the dual fluidised bed technology use wood chips from forestry as fuel. However, increasing fuel flexibility will be necessary for future applications, mainly due to economical reasons. Thus, different alternative biomass fuels have been tested and it can be stated that all of them could be used without major problems. Only straw, or in general fuels with high ash contents and therefore low ash melting points, might create operational problems.

The tar content in the product gas is influenced by the fuel water content and the process parameters, such as steam/fuel ratio, gasification temperature, etc. Higher water
Fig. 15 Effect of different bed materials on product gas composition [37]

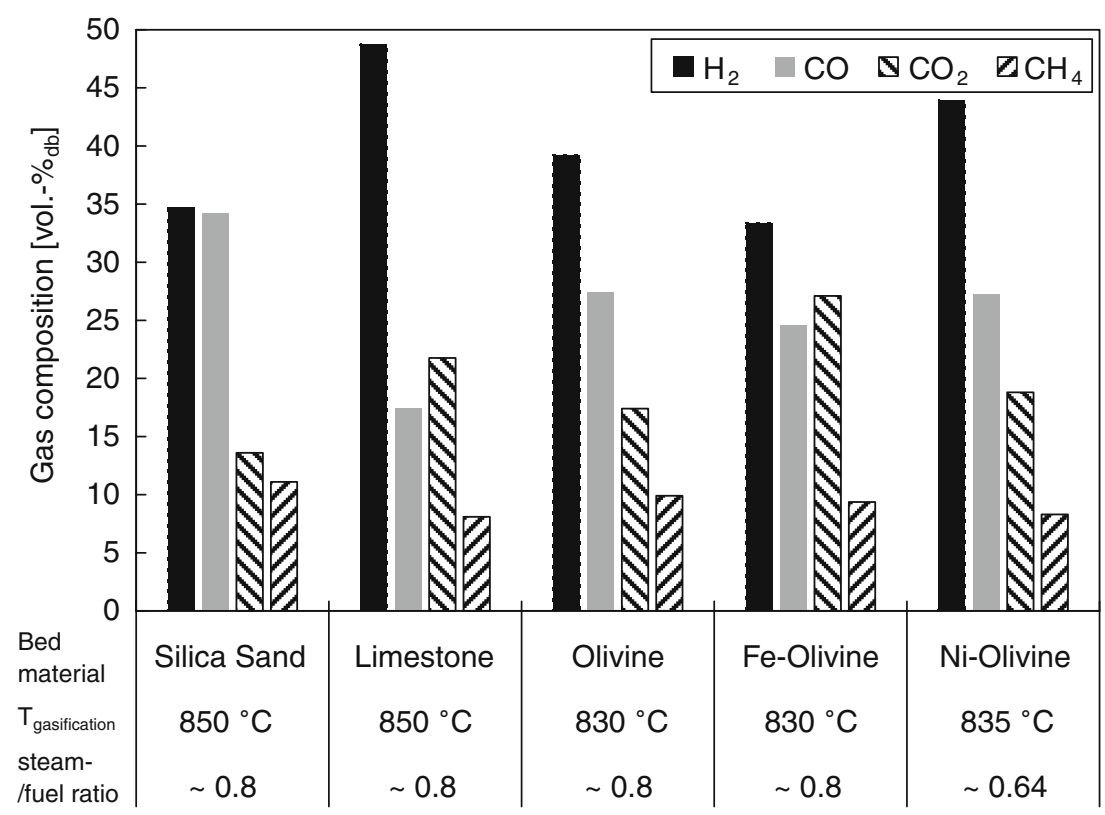


contents, steam/fuel ratios and gasification temperatures lead to lower levels of hydrocarbons and especially tars, but decrease the overall efficiency of the plant. Therefore, an optimum has to be found which is influenced by the gas cleaning system and the energy balance of the whole plant. For example, drying of biomass is energetically advantageous since it becomes, due to the increasing demand, more and more difficult to ensure the supply with dry biomass. The highest energetic benefit can be achieved if low temperature heat is used for this purpose. As optimum moisture content of the fuel feedstock about $20 \mathrm{wt} . \%$ has been found since the fuel moisture content has much more influence than the steam/fuel ratio.

If high hydrogen contents are needed, a catalytically active bed material (e.g. limestone) or the addition of lignite or coal can be applied. Moreover, the application of the dual fluidised bed steam gasification process coupled with $\mathrm{CO}_{2}$ capture (the so-called AER process) results in high hydrogen contents.

Dual fluidised bed steam gasification technology has been demonstrated commercially at the $8-\mathrm{MW}_{\text {Fuel input }}$ biomass combined heat and power (CHP) plant in Güssing/Austria since 2001 as well as at the biomass CHP in Oberwart/Austria since 2008. The experience gained with the $100-\mathrm{kW}$ process development units provided the basis for the commercial breakthrough of biomass gasification. This process is very flexible with regard to fuels and, depending on the gas utilisation route, the process parameters can be adopted according to need.

Acknowledgements The authors gratefully acknowledge the financial support by the European Union under various contracts (AER Gas, JOR3-CT97-0196; AERGas II, 518309; BiGPower, 019761; CleanEnergy, ENK5-CT2000-0314; Flexgas, RFCR-CT-2007-0005; and Unique, 211517), by the Renewable Energy Network Austria (ReNet) (Austrian funds program $\mathrm{K}_{\mathrm{NET}} / \mathrm{K}_{\mathrm{IND}}$ ) and by the projects $\mathrm{G}$ volution and G-volution II under the "New Energies 2020" calls of the Austrian Climate and Energyfund processed by the Austrian Research Promotion Agency (FFG). Moreover, the support and input of numerous colleagues, who contributed to the generation of the data used for this publication, is deservedly mentioned here. Finally, the authors would like to express their thanks to the team members of the "Testing Laboratory for Combustion Systems" at the Vienna University of Technology for the measurements as well as the support in analytical concerns.

\section{References}

1. Paasen SVB, Kiel JHA (2004) Tar formation in a fluidised-bed gasifier. Report prepared at the Energy research Centre of the Netherlands (ECN), report no: ECN-RX-04-037

2. Simell P (1997) Catalytic hot gas cleaning of gasification gas. $\mathrm{PhD}$ thesis, Helsinki University of Technology Finland

3. Jörg K (2003) Abwasserfreie Abscheidung von Partikeln und Teeren aus Holzgas. PhD thesis, Vienna University of Technology, Austria
4. Bridgwater AV (1999) Review of thermochemical biomass conversion. Energy Technology Support Unit (ETSU), Harwell, report no: ETSU B 1202

5. Kaltschmitt M, Hartmann H (2001) Energie aus Biomasse. Springer Verlag, ISBN 3-540-64853-4, Berlin Heidelberg, Germany

6. Rauch R (2000) Erzeugung eines Synthesegases aus Biomasse. $\mathrm{PhD}$ thesis, Vienna University of Technology, Austria

7. Higman C, van der Burgt M (2003) Gasification. Gulf Professional Publishing, ISBN 0-7506-7707-4, Burlington, USA

8. Milne TA, Evans RJ, Abatzoglou N (1998) Biomass gasifier "tars": their nature, formation and conversion. National Renewable Energy Laboratory, Golden, CO, report no: NREL/TP570-25357

9. Bridgwater AV (2003) Renewable fuels and chemicals by thermal processing of biomass. Chem Eng J 91:87-102

10. Corella J, Toledo JM, Molina G (2007) A review on dual fluidized-bed biomass gasifiers. Ind Eng Chem Res 46 (21):6831-6839. doi:10.1021/ie0705507

11. Frey H (2007) Fuel variation at the dual fluidized bed steam gasification. Master thesis, Vienna University of Technology, Austria

12. Göransson K, Söderlind U, He J, Zhang W (2011) Review of syngas production via biomass DFBGs. Renew Sust Energ Rev 15:482-492

13. Wei L, Xu S, Liu J, Lu C, Liu S, Liu C (2006) A novel process of biomass gasification for hydrogen-rich gas with solid heat carrier: preliminary experimental results. Energy Fuels 20:2266-2273

14. Hamel S, Hasselbach H, Weil S, Krumm W (2007) Autothermal two-stage gasification of low-density waste-derived fuels. Energy 32:95-107

15. Murakami T, Xu G, Suda T, Matsuzawa Y, Tani H, Fujimori T (2007) Some process fundamentals of biomass gasification in dual fluidized bed. Fuel 86:244-255

16. Thunman H, Seemann MC (2009) First experiences with the new Chalmers gasifier. In: 20th International conference on fluidized bed combustion, May 18-20, 2009, Xi'an, China

17. Bull D, Gilmour I, Williamson C, Pang S (2009) The development and operation of a $100 \mathrm{~kW}$ dual fluidised bed biomass gasifier for production of high quality producer gas, ICPS 09 (International Conference on Polygeneration Strategies) Vienna, Austria

18. Hofbauer H, Veronik G, Fleck T, Rauch R (1997) The FICFB gasification process. In: Bridgwater AV, Boocock D (eds) Developments in thermochemical biomass conversion, vol 2, Blackie Academic \& Professional. Glasgow, UK, pp 1016-1025

19. Hofbauer H, Rauch R, Loeffler G, Kaiser S, Fercher E, Tremmel H (2002) Six years experience with the FICFB-gasification process. 12th European Biomass Conference. ETA, Florence, pp 982-985

20. Lin S, Harada M, Suzuki Y, Hatano H (2004) Continuous experiment regarding hydrogen production by $\mathrm{coal} / \mathrm{CaO}$ reaction with steam (I) gas products. Fuel 83:869-874

21. Lin S, Harada M, Suzuki Y, Hatano H (2005) Process analysis for hydrogen production by reaction integrated novel gasification (HyPr-RING). Energ Convers Manag 46(6):869-880

22. Shimizu T, Hirama T, Hosada H, Kitano K, Inagaki M, Tejima K (1999) A twin fluid-bed reactor for removal of $\mathrm{CO}_{2}$ from combustion processes. Chem Eng Res Design 77(1):62-68. doi: $10.1205 / 026387699525882$

23. Sun P, Grace JR, Lim CJ, Anthony EJ (2007) On the effect of $\mathrm{CaO}$ sintering on cyclic $\mathrm{CO} 2$ capture in energy systems. AIChE J 53(9):2432-2442

24. Milne TA, Evans RJ (1998) Biomass gasifier "tars": their nature, formation and conversion, NREL/TP-570-25357

25. Evans RJ, Milne TA (1987) Molecular characterization of the pyrolysis of biomass. Energy Fuels 1:123-137

26. Pfeifer C, Puchner B, Hofbauer $\mathrm{H}$ (2007) In-situ $\mathrm{CO}_{2}$-absorption in a dual fluidized bed biomass steam gasifier to produce a hydrogen rich syngas. Int J Chem Reactor Eng 5:A9 
27. Marquard-Moellenstedt T, Specht M, Zuberbuehler U, Koppatz S, Pfeifer C, Rauch R, Soukup G, Hofbauer H, Koch M (2008) Transfer of absorption enhanced reforming process (AER) from pilot scale to an $8 \mathrm{MW}$ gasification plant in Güssing, Austria, 16th European Biomass Conference \& Exhibition, Valencia, Spain, pp 684-689

28. Koppatz S, Pfeifer C, Rauch R, Hofbauer H, MarquardMoellenstedt T, Specht M (2009) $\mathrm{H}_{2}$ rich product gas by steam gasification of biomass with in situ $\mathrm{CO}_{2}$ absorption in a dual fluidized bed system of $8 \mathrm{MW}$ fuel input. Fuel Process Technol 90 (7-8):914-921. doi:10.1016/j.fuproc.2009.03.016

29. Bi HT, Grace JR (1995) Flow regime diagrams for gas-solid fluidization and upward transport. Int J Multiph Flow 21:12291236

30. Hofbauer H, Rauch R (2000) Stoichiometric water consumption of steam gasification by the FICFB-gasification process. Progress in Thermochemical Biomass Conversion, Innsbruck

31. Koppatz S, Pfeifer C, Hofbauer H (2009) Primary tar reduction in a dual fluidised bed gasification system by means of Fe-supported olivine. 17th European Biomass Conference \& Exhibition, Hamburg, Germany

32. Pfeifer C, Hofbauer H, Rauch R (2004) In-bed catalytic tar reduction in a dual fluidized bed biomass steam gasifier. Ind Eng Chem Res 43:1634-1640

33. Aigner I (2010) Co-gasification of coal and wood with steam in a dual fluidized bed gasifier. $\mathrm{PhD}$ thesis, Vienna University of Technology, Austria

34. Abu El-Rub Z, Bramer EA, Brem G (2004) Review of catalysts for tar elimination in biomass gasification processes. Ind Eng Chem Res 43:6911-6919. doi:10.1021/ie0498403
35. Sutton D, Kelleher B, Ross JRH (2001) Review of literature on catalysts for biomass gasification. Fuel Process Technol 73:155173

36. Dayton D (2002) A review of the literature on catalytic biomass tar destruction. National Renewable Energy Laboratory, Golden, report no: NREL/TP-510-32815, 2002

37. Koppatz S, Pfeifer C, Kreuzeder A, Soukup G, Hofbauer H (2009) Application of $\mathrm{CaO}$-based bed material for dual fluidized bed steam biomass gasification. In: Proceedings of the 20th international conference on fluidized bed combustion conference, Volume II, Xi'an, China, ISBN 978-7-302-20146-5, pp 712-718

38. Pröll T, Hofbauer $\mathrm{H}(2008) \mathrm{H}_{2}$ rich syngas by selective $\mathrm{CO}_{2}$ removal from biomass gasification in a dual fluidized bed system -process modelling approach. Fuel Process Technol 89 (11):1207-1217

39. Soukup G, Pfeifer C, Kreuzeder A, Hofbauer H (2009) In situ $\mathrm{CO}_{2}$ capture in a dual fluidized bed biomass steam gasifier-bed material and fuel variation. Chem Eng Technol 32(3):348-354

40. Höftberger E (2005) In-situ $\mathrm{CO}_{2}$-adsorption in a dual fluidised bed biomass steam gasifier to produce a hydrogen rich gas. $\mathrm{PhD}$ thesis, Vienna University of Technology, Austria

41. Pfeifer C, Koppatz S, Hofbauer H (2010) Catalysts for fluidized bed biomass gasification-overview on recent developments and applications. In: Proceedings of the international conference on polygeneration strategies (ICPS), 7-9 September 2010, Leipzig, Germany

42. Koppatz S, Pfeifer C, Hofbauer H (2010) Application of Feolivine as catalytic active bed material in biomass gasification. In: Proceedings of the international conference on polygeneration strategies (ICPS), 7-9 September 2010, Leipzig, Germany 